\title{
Effect of neem seed extracts on the development of the Soybean Cysts Nematode
}

\author{
Júlio C.T. Silva1, Rosângela D.L. Oliveira², Gulab N. Jham ${ }^{1}$ \& Naylor D.C. Aguiar ${ }^{2}$ \\ ${ }^{1}$ Departamento de Química; ${ }^{2}$ Departamento de Fitopatologia, Universidade Federal de Viçosa, 36570-000, Viçosa, MG, \\ Brazil
}

Author for correspondence: Rosângela D’Arc de Lima Oliveira, e-mail: rdlima@ufv.br

\begin{abstract}
The effect produced by neem seed extracts and a neem seed concentrate (NSC) on the mortality and development of Heterodera glycines was evaluated. Second-stage juvenile (J2) mortality produced by the extracts and NSC was determined. Soybean seedlings treated with each of the extracts (aqueous, methanolic and hexane) were inoculated with $\mathrm{J} 2$ and the number of females and eggs per root system determined after 30 days. Both the hexane extracts were ineffective as no statistical difference $(\mathrm{P}>0.05)$ in $\mathrm{J} 2$ mortality was observed between them and the control. No statistical difference $(\mathrm{P}>0.05)$ in $\mathrm{J} 2$ mortality $(>98 \%)$ was obtained between the water extracts and methanol extract at $1000 \mathrm{mg} \mathrm{L}^{-1}$ treatments. The $\mathrm{J} 2$ percentage of mortality exponentially increased with the $\mathrm{NSC}$ dosages $\left(\mathrm{R}^{2}=0.94\right)$. $\mathrm{LD}_{50}$ was $42.6 \mathrm{mg} \mathrm{L}^{-1}$ for NSC on $H$. glycines. In the greenhouse experiment, the highest reduction in the number of females was $84 \%$, obtained with the aqueous $\left(41.6 \mathrm{mg} \mathrm{L}^{-1}\right)$ and methanolic extracts $\left(1000 \mathrm{mg} \mathrm{L}^{-1}\right)$. In the same way, the highest reduction in the number of eggs, of about $90 \%$, was obtained with the same extracts. Thus, using aqueous extracts is more suitable than the remaining extracts in field conditions. The activities of the methanol and NSC extracts were attributed to the seven tetranortritepenoids (azadirachtin H, azadirachtin A, azadirachtin B, desacetylnimbin, desacetylsalannin, nimbin and salannin) identified by reverse phase high performance liquid chromatography.
\end{abstract}

Keywords: Azadirachta indica, Heterodera glycines, tetranortriterpenoids, control.

\section{RESUMO}

Efeito dos extratos de sementes de Nim no desenvolvimento de Heterodera glycines

O efeito dos extratos de sementes de nim e do extrato de sementes concentrado (NSC) foi avaliado na mortalidade e desenvolvimento de Heterodera glycines. A mortalidade de juvenis de segundo estádio (J2) foi avaliada na presença dos extratos de sementes (aquosos, metanólicos e hexânicos) e NCS in vitro. Em casa de vegetação, o número de fêmeas e de ovos por sistema radicular foi determinado 30 dias após a inoculação de plantas de soja com J2 tratados com os extratos de sementes. Os extratos hexânicos foram ineficientes em matar os J2, conquanto nenhuma diferença estatística $(\mathrm{P}>0.05)$ foi observada entre as doses estudadas e a testemunha. Os extratos aquosos e o metanólico a $1000 \mathrm{mg} \mathrm{L}^{-1}$ causaram a morte de pelo menos $98 \%$ dos $\mathrm{J} 2$, mas não houve diferença significativa entre estes tratamentos. A mortalidade dos $\mathrm{J} 2$ tratados com NSC cresceu exponencialmente com o aumento das doses $\left(\mathrm{R}^{2}=0.94\right)$. O $\mathrm{LD}_{50}$ do NSC sobre $\mathrm{J} 2$ de $H$. glycines foi de $42.6 \mathrm{mg} \mathrm{L}^{-1}$. Em casa de vegetação, as maiores reduções no número de fêmeas, $84 \%$, foram obtidas com o extrato aquoso (41.6 mg $\left.\mathrm{L}^{-1}\right)$ e metanólico (1000 $\left.\mathrm{mg} \mathrm{L}^{-1}\right)$. Da mesma forma, as maiores reduções no número de ovos, cerca de $90 \%$, foram obtidas com os mesmos extratos. Considerou-se que o uso do extrato aquoso em condições de campo é mais apropriado que os demais extratos. As atividades do extrato metanólico e do NSC foram atribuídas a sete tetranortriterpenóides (azadiractina $\mathrm{H}$, azadiractina A, azadiractina B, desacetilnimbim, desacetilsalanim, nimbim and salanim) que foram identificados por cromatografia líquida de alta performance de fase reversa.

Palavras-chave: Azadirachta indica, nematóide de cistos da soja, controle, tetranortriterpenóides.

\section{INTRODUCTION}

The nematode Heterodera glycines Ichinohe is currently considered to be one of the principal soybean pests found worldwide, and it causes heavy economic losses (Dias et al., 2007). It was reported in Brazil for the first time in 1991/1992 in the States of Minas Gerais, Mato Grosso and Mato Grosso do Sul, infecting about 10,000 ha of soybean crop (Mendes, 1993). Today, it has been estimated that more than 2 million ha are infested, producing estimated annual losses of about 70 million dollars (Silva \& Garcia, 2004). Being a cyst nematode it has a high survival capacity and is readily disseminated, making its control difficult. Crop rotation and the use of resistant varieties are the main control methods, although the latter cannot be used for extended periods due to the high genetic variability of the nematode (Dias et al., 2007). Application of toxic nematicides is also used for its control, causing problems to human health as well as to the environment. Ecologically safe methods for its control are highly desirable.

The neem tree (Azadirachta indica A. Juss) is a source of natural pesticides, showing activity against 400 insect pests (National Research Council, 1992; Siddiqui \& Alam, 1993; Kumar et al., 1996; Martinez, 2002; Mourão et 
al., 2004). Its vegetative parts reduce populations of several nematode species that attack soybean (Vyas, 1993, Gupta et al., 1993; Khurma \& Singh, 1997; Akhtar \& Akhtar, 2000) and several other plants, i.e., tomato (Rossner \& Zebitz, 1986), okra (Rao et al., 1997), cowpea (Mojumder \& Mittal, 2003), pigeonpea (Nageswari \& Mishra, 2001, 2005), and rice (Prasad et al., 2005).

Several reports are available about bioactive secondary metabolites of neem (Barek et al., 2004; Sharma et al., 2003; Silva et al., 2007). Among the large numbers of tetranortriterpenoids isolated from various parts of $A$. indica, azadirachtin $\mathrm{A}$ and its congeners have been found to exhibit biological activity. In a preliminary study, a significant mortality ( $>99 \%$ ) of $\mathrm{H}$. glycines was induced by the aqueous extracts of neem leaves and seeds (Rodrigues et al., 2001). The aim of this study was to evaluate the effect produced by neem seed extracts sequentially extracted with hexane, methanol and water along with a neem seed concentrate (NSC) on the mortality and development of $H$. glycines, in experiments carried out in vitro and in greenhouse conditions.

\section{MATERIALS AND METHODS}

\section{Production of second-stage juveniles (J2) of Heterodera glycines}

H. glycines nematodes (race 3) were multiplied on soybean, Glycine $\max (\mathrm{L})$ Merr. cv. Conquista, in greenhouse pots. In order to prepare the inoculum, soybean roots were carefully removed from the pots, immersed in water to remove the excess of soil and placed on two sieves in series (the first had an aperture of $0.85 \mathrm{~mm}$ and the second $0.15 \mathrm{~mm}$ ). The sieves were washed in a strong jet of running water to remove the female cysts from the root system. The females retained on the second sieve were homogenized in a tissue grinder and the eggs collected on a sieve $(0.025 \mathrm{~mm})$. The egg suspension was placed in a hatch chamber (Lima \& Ferraz, 1985). J2 were collected after 24 to 48 hours. The juveniles were counted using a Peter's chamber with a light microscope and the suspension was calibrated to 1,000 juveniles per $\mathrm{mL}$ unless otherwise specified.

\section{Preparation of crude neem seed extracts}

The extraction of substances from seeds was carried out in a sequential manner with hexane, methanol and water. De-hulled neem seeds ( $50 \mathrm{~g}$, purchased from Bionim, Brazil) were extracted with distilled hexane $(200 \mathrm{~mL})$ on a magnetic stirrer for eight hours at room temperature and the solution was filtered. The extraction was repeated twice more and filtrates from the three extractions combined. The combined hexane extracts were pooled and evaporated on a rotatory evaporator at $30^{\circ} \mathrm{C}$ to obtain $9 \mathrm{~g}$ of oil, which after dilution in Tween $80^{\circledR}$ :water $(1: 99, \mathrm{v} / \mathrm{v})$ gave solutions containing 1,000 and $100 \mathrm{mg} \mathrm{L}^{-1}$. The residue from hexane extraction was similarly extracted three times with methanol $(200 \mathrm{~mL}$ each $)$ to obtain $4 \mathrm{~g}$ of oil, which after dilution in Tween $80^{\circledR}$ : water
$(1: 99, \mathrm{v} / \mathrm{v})$ gave solutions containing 1,000 and $100 \mathrm{mg} \mathrm{L}^{-1}$. The residue from methanol extraction was dried in an oven at $40^{\circ} \mathrm{C}$ and $5 \mathrm{~g}$ were extracted twice with distilled water $(30$ $\mathrm{mL}$ each) for $12 \mathrm{~h}$ on a magnetic stirrer. Two portions ( 25 $\mathrm{mL}$, containing $2.08 \mathrm{~g}$ of the residue) of the above solution were diluted with water $(25$ and $475 \mathrm{~mL})$ to produce two solutions (41.6 and $\left.4.16 \mathrm{mg} \mathrm{L}^{-1}\right)$. All extracts were stored in a freezer at $-10^{\circ} \mathrm{C}$ until evaluation. The $\mathrm{J} 2$ mortality and $H$. glycines development were evaluated in vitro as well as in a greenhouse by using the above six solutions (two each of hexane, methanol and aqueous).

\section{Preparation of neem seed concentrate (NSC)}

The NSC rich in tetranortriterpenoids was prepared according to Sharma et al. (2003) with slight modification. Briefly, $500 \mathrm{~g}$ of de-hulled ground neem seed was extracted three times with hexane $(500 \mathrm{~mL})$ in a magnetic stirrer for eight hours at room temperature $\left(25^{\circ} \mathrm{C}\right)$ and the oil obtained after vacuum filtration was discarded. The NSC residue from hexane extraction was extracted three times in a magnetic stirrer for $8 \mathrm{~h}$ (after each solvent addition) at room temperature with methanol. The residue from the methanol extraction was discarded and the combined solutions were evaporated at $40^{\circ} \mathrm{C}$ in a rotatory evaporator; the oil obtained was dissolved in ethyl acetate $(500 \mathrm{~mL})$ and extracted twice with hexane and water $(500 \mathrm{~mL}$ each). The procedure was repeated twice more. The ethyl acetate layer was treated with activated charcoal $\left(4 \mathrm{~g}\right.$ at $60^{\circ} \mathrm{C}$ for $\left.25 \mathrm{~min}\right)$, filtered and the solution concentrated at $30^{\circ} \mathrm{C}$ in a rotatory evaporator to obtain viscous orange oil $(9 \mathrm{~g})$. The oil was dissolved in ethyl acetate $(10 \mathrm{~mL})$ and compounds precipitated with an excess of hexane to obtain a residue $(7.7 \mathrm{~g})$. The process of charcoal addition was repeated twice more to obtain $4 \mathrm{~g}$ of a brownish white powder. An appropriate amount of this powder was dissolved in Tween $80^{\circledR}$ : water $(1: 99, \mathrm{v} / \mathrm{v})$ to obtain a solution containing $100 \mathrm{mg} \mathrm{L}^{-1}$, which was diluted to obtain solutions of $10,1,0.1$ and $0.01 \mathrm{mg} \mathrm{L}^{-1}$ of the residue.

\section{In vitro effects of the crude neem seed extracts and neem seed concentrate (NSC) on second-stage juvenile (J2) mortality}

J2 mortality was determined by the procedure of Rodrigues et al. ( 2001) and was based on the method described by Kimura et al. (1981). Briefly, $2.5 \mathrm{~mL}$ of the crude extracts were placed in a test tube $(5 \times 1.5 \mathrm{~cm})$ containing $0.1 \mathrm{~mL}$ of the nematode suspension. The tubes were closed with two layers of permeable tissue paper and stored for $24 \mathrm{~h}$ at $26^{\circ} \mathrm{C}$. At the end of the storage period, the tubes were inverted over a Petri dish $(5 \mathrm{~cm}$ in diameter) and stored for another $24 \mathrm{~h}$. At the end of this period, the number of nematodes in the Petri dish was counted using a stereoscopic microscope. All the nematodes found in the Petri dish were considered to be alive since they were sufficiently mobile to pass through the two layers of the tissue paper. Complementarily, juveniles were treated with a solution of $1 \mathrm{M} \mathrm{NaOH}$ to confirm if they had remained 
alive. Those which remained straight without trembling were considered to be dead (Chen \& Dickson, 2000). Water was used as control since no difference was obtained when it and Tween $80^{\circledR}$ :water $(1: 99, \mathrm{v} / \mathrm{v})$ were compared. Each treatment was repeated seven times and the design adopted was completely randomized.

For determination of the effect of the NSC, the J2 suspension was diluted with water to obtain a suspension containing $147 \mathrm{~J} 2$ per $\mathrm{mL}$. This was placed in a test tube, and to it were added $1 \mathrm{~mL}$ of the nematode suspension and $2.4 \mathrm{~mL}$ of the solution containing each of the different concentrations of the purified methanolic extract. Thus, the final concentrations of the NSC residue was $0.007,0.07$, $0.7,7$ and $70 \mathrm{mg} \mathrm{L}^{-1}$. After $48 \mathrm{~h}$, the number of live $\mathrm{J} 2$ was counted. This test was performed in a completely randomized design and each treatment was repeated six times. Data were submitted to regression analysis. The mortality percentage (average) produced by each extract was calculated from the equation:

$$
\% \text { Mortality (average })=100-(\mathrm{Yx} 100) / \mathrm{X}
$$

where $\mathrm{X}$ and $\mathrm{Y}$ are the numbers of nematodes recovered from the treatment in relation to the control (water).

Evaluation of Heterodera glycines development on soybean treated with crude neem seed extracts (hexane, methanol and aqueous)

Three soybean cv. Conquista seedlings were placed in a pot containing $2 \mathrm{~L}$ of soil:sand (1:1), pretreated with methyl bromide. After germination, two seedlings were removed leaving one plant per pot. In an Erlenmeyer flask, $35 \mathrm{~mL}$ of the dissolved neem extracts (hexane, methanolic and aqueous) were placed along with $1 \mathrm{~mL}$ of the nematode suspension containing $1,100 \mathrm{H}$. glycines $\mathrm{J} 2$, and the flask was stored at $26^{\circ} \mathrm{C}$ in daylight for $24 \mathrm{~h}$. After this, each pot containing one soybean plant was inoculated with $5 \mathrm{~mL}$ of this suspension and maintained in a greenhouse for 30 days. After this period, the plants were removed from the pots and the aerial part discarded. The females were extracted from the roots as described earlier and the number of females was counted before the females were crushed in the tissue grinder to get the eggs. The eggs were extracted and counted as described previously. This test was performed in a completely randomized design and each treatment was repeated five times. The data regarding number of females was transformed in $\sqrt{ } \mathrm{x}+1 / 2$ and all data were submitted to variance analysis; the averages were compared with the Tukey or Scott-Knott test (5\% probability) using the SAEG program (Euclydes, 1983). The percentage of reduction (average) in the number of females or eggs produced by the extracts was calculated from the equation:

Reduction (\%) in the number of females or eggs = $100-(Y \times 100) / X$, where $\mathrm{X}$ and $\mathrm{Y}$ are the numbers of females or eggs recovered from the treatment in relation to the control (water), respectively.

\section{Qualitative HPLC analysis}

Methanolic and NSC extracts - Analyses were conducted using a liquid chromatograph (Shimadzu, Osaka, Japan, model LC-6AD), with UV-VIS detector (Shimadzu, Osaka, Japan, model SP-10AVP with cell volumes of $7 \mu \mathrm{L}$ ) set at $217 \mathrm{~nm}$, data collection system (Shimadzu, Osaka, Japan, CBM 101 with a microcomputer) equipped with a Rheodyne injector. The reverse phase column (LC-18, 5 $\mu \mathrm{m}, 250 \times 4.6 \mathrm{~mm}$ id, Supelco) and the pre-column were purchased from Supelco (Bellefonte, PA). Separations were carried out using the following linear gradient methanol: water at flow-rate of $0.8 \mathrm{~mL} \mathrm{~min}^{-1}: 0$ to $10 \mathrm{~min}, 50 \% \mathrm{MeOH}$; 10 to $20 \mathrm{~min}, 50$ to $55 \% \mathrm{MeOH} ; 20$ to $30 \mathrm{~min}, 55$ to $65 \%$ $\mathrm{MeOH} ; 30$ to $40 \mathrm{~min}, 65$ to $70 \% \mathrm{MeOH} ; 40$ to $50 \mathrm{~min}$ and 70 to $100 \% \mathrm{MeOH}$. Identification of the peaks was carried out comparing the retention times of the peaks with those of standards (azadirachtin H, azadirachtin A, azadirachtin B, desacetylnimbin, desacetylsalannin, nimbin, salannin) kindly donated by Dr. Gopalakrishnan, SPIC Science Foundation, Madras, India.

Aqueous extract - The aqueous extract was analyzed by the same liquid chromatograph with a refractive index detector (RID) (Shimazdu, Kyoto, Japan, model RID 10A). The mobile phase was acetonitrile/water $(6: 4, \mathrm{v} / \mathrm{v})$ at a flow rate of $0.5 \mathrm{~mL} \mathrm{~min}{ }^{-1}$. Techsphere column $\left(\mathrm{NH}_{2}, 5 \mu \mathrm{mm}\right.$, $250 \times 4.6 \mathrm{~mm}$ id, HPLC Technology, Herts, England) and a guard-column $\left(\mathrm{NH}_{2}, 5 \mu \mathrm{mm}, 10 \times 4.6 \mathrm{~mm}\right)$ were used.

\section{RESULTS}

Second-stage juvenile (J2) mortality produced by the crude neem seed extracts and neem seed concentrate (NSC)

The hexane extracts were ineffective, causing less than $20 \%$ of J2 mortality. No statistical difference ( $\mathrm{P}>0.05)$ was observed among the dosages (Figure 1). The average J2 mortality treated with aqueous extracts ( 41.6 and $\left.4.16 \mathrm{mg} \mathrm{L}^{-1}\right)$ did not differ statistically $(\mathrm{P}>0.05)$ between dosages or from the methanolic extract treatment at $1,000 \mathrm{mg} \mathrm{L}^{-1}$. However, a lower dosage of methanolic extract $\left(100 \mathrm{mg} \mathrm{L}^{-1}\right)$ caused lower $(\mathrm{P} \leq 0.05) \mathrm{J} 2$ mortality. With the water extracts and the methanolic extract $\left(1,000 \mathrm{mg} \mathrm{L}^{-1}\right)$ the average mortality was $>98 \%$; with the methanolic extract $\left(100 \mathrm{mg} \mathrm{L}^{-1}\right)$ the average mortality was $48.13 \%$. Thus, the water extract was about 240 times more effective than the methanolic extract (4.16 vs. $1000 \mathrm{mg}$ ).

The NSC was active against $H$. glycines at a dosage above $11.6 \mathrm{mg} \mathrm{L}^{-1}$ (Figure 2). Highest J2 mortality of 92.4 $\%$ was produced at a concentration of $70 \mathrm{mg} \mathrm{L}^{-1}$. The mortality percentage increased exponentially with dosage $\left(\mathrm{R}^{2}=0.94\right)$, reaching a maximum $(100 \%)$ at $73.5 \mathrm{mg} \mathrm{L}^{-1}$. At lower dosages there was a minimal increase in the number 

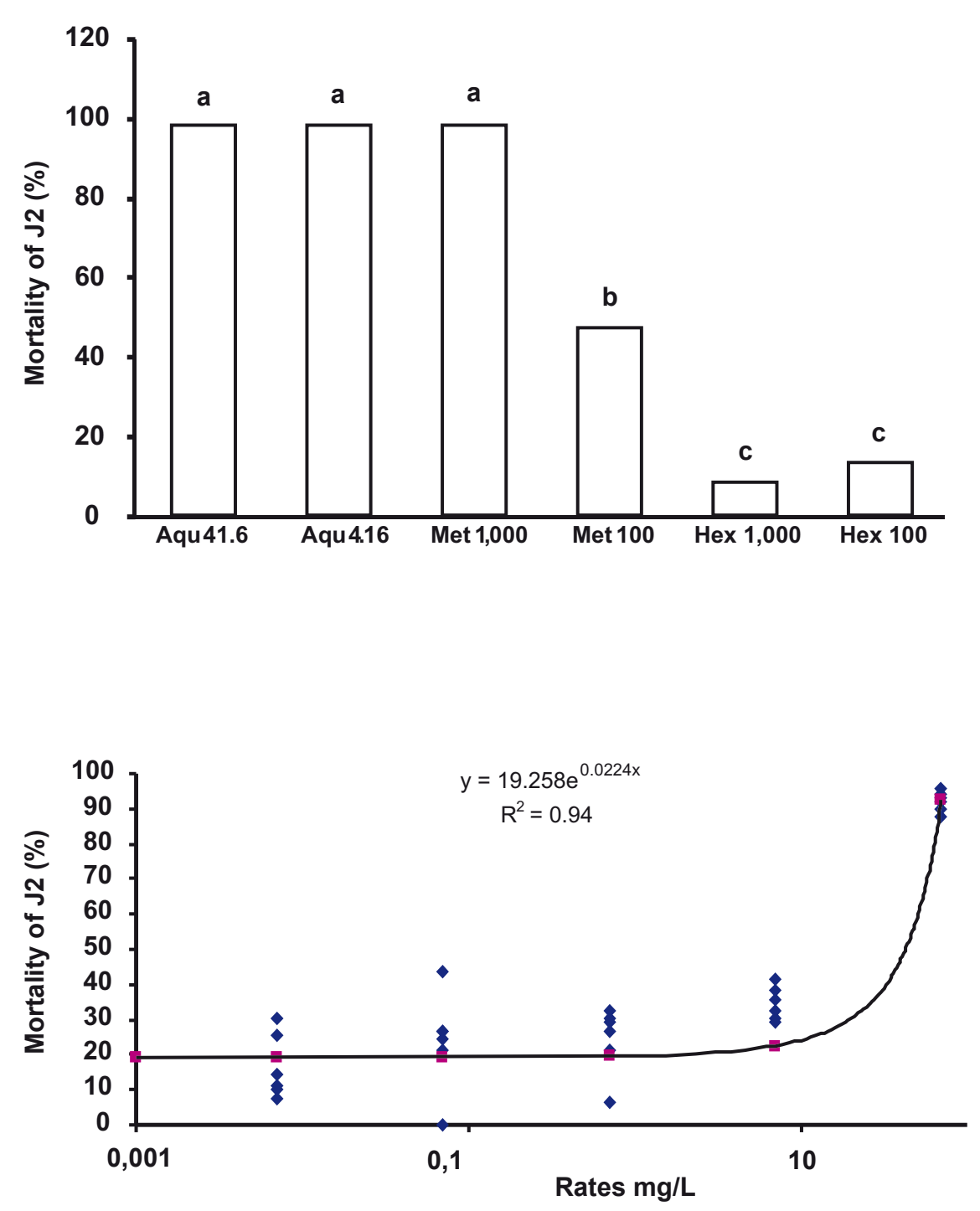

FIG. 1 - Average mortality of Heterodera glycines second-stage juveniles (J2) after treatment with neem seed extracts. $(n=7$ replicates). Data transformed in $\sqrt{x+1 / 2}$. Averages followed by the same letter do not differ by the Tukey test $(\mathrm{P}=0.05)$. Aqu 4.16 and Aqu 0.416 represent treatments with aqueous extract at a concentration of 41.6 and $4.16 \mathrm{mg} \mathrm{L}^{-1}$; Met 1,000 and Met $100=$ methanolic extract at a concentration of 1000 and $100 \mathrm{mg} \mathrm{L}^{-1}$; Hex 1,000 and Hex $100=$ hexane extract at a concentration of 1000 and $100 \mathrm{mg} \mathrm{L}^{-1}$, respectively.
FIG. 2 - Mortality percentage of Heterodera glycines second-stage juveniles (J2) after treatment with different dosages of neem seed concentrate (NSC) extract. of dead $\mathrm{J} 2$ until a dosage of $11.6 \mathrm{mg} \mathrm{L}^{-1}$. At this dosage, the percentage of mortality of $\mathrm{J} 2$ was around $30 \%$. The in vitro assay showed that the $\mathrm{LD}_{50}$ of NSC was $42.6 \mathrm{mg} \mathrm{L}^{-1}$.

\section{Effect of neem extracts on development of Heterodera glycines on soybean plants}

Average number of $H$. glycines females after 30 days on soybean plants inoculated with $\mathrm{J} 2$ treated with the aqueous neem extract $\left(41.6 \mathrm{mg} \mathrm{L}^{-1}\right)$ or with methanolic neem extracts $\left(1,000 \mathrm{mg} \mathrm{L}^{-1}\right)$ differed from the control $(\mathrm{P}>0.05)$ but not between extracts (Figure $3 \mathrm{~A}$ ). Thus, the aqueous extract was about 24 times more effective than the crude methanolic extract (41.6 vs $1000 \mathrm{mg} \mathrm{L}^{-1}$ ).

Juveniles that were treated with the other extracts or which received control treatment reached complete development. The number of eggs per root system was significantly reduced when $\mathrm{J} 2$ treated with aqueous (41.6 and $\left.4.16 \mathrm{mg} \mathrm{L}^{-1}\right)$ and methanolic $\left(1,000 \mathrm{mg} \mathrm{L}^{-1}\right)$ extracts were inoculated (Figure 3B). In these treatments, the treated J2 completed their life cycle and produced 9.5, 3.0 and 9.7 times fewer eggs than the control, respectively. Once again, the aqueous extract was about 24 times more effective than the methanolic extract.

The percentage of control of $H$. glycines females varied significantly in different extracts. Both the aqueous extracts $\left(41.6\right.$ and $\left.4.16 \mathrm{mg} \mathrm{L}^{-1}\right)$ were as effective as the more concentrated methanolic extract $(\mathrm{P}>0.05)$ in reducing the number of females, and more effective than the other extracts (Figure 4). These treatments showed a reduction of 84, 62 and $84 \%$ in the number of females. Comparing the reproduction of the soybean cyst nematode, the reduction in the number of eggs was higher (93\%) in the more concentrated aqueous extract than in the less concentrated one $(81 \%)$, but they did not differ from the methanolic extract at $1000 \mathrm{mg} \mathrm{L}^{-1}$ (89\%). The control of $H$. glycines was significantly lower in the hexane extracts $(<48 \%)$ and methanolic extract at 100 

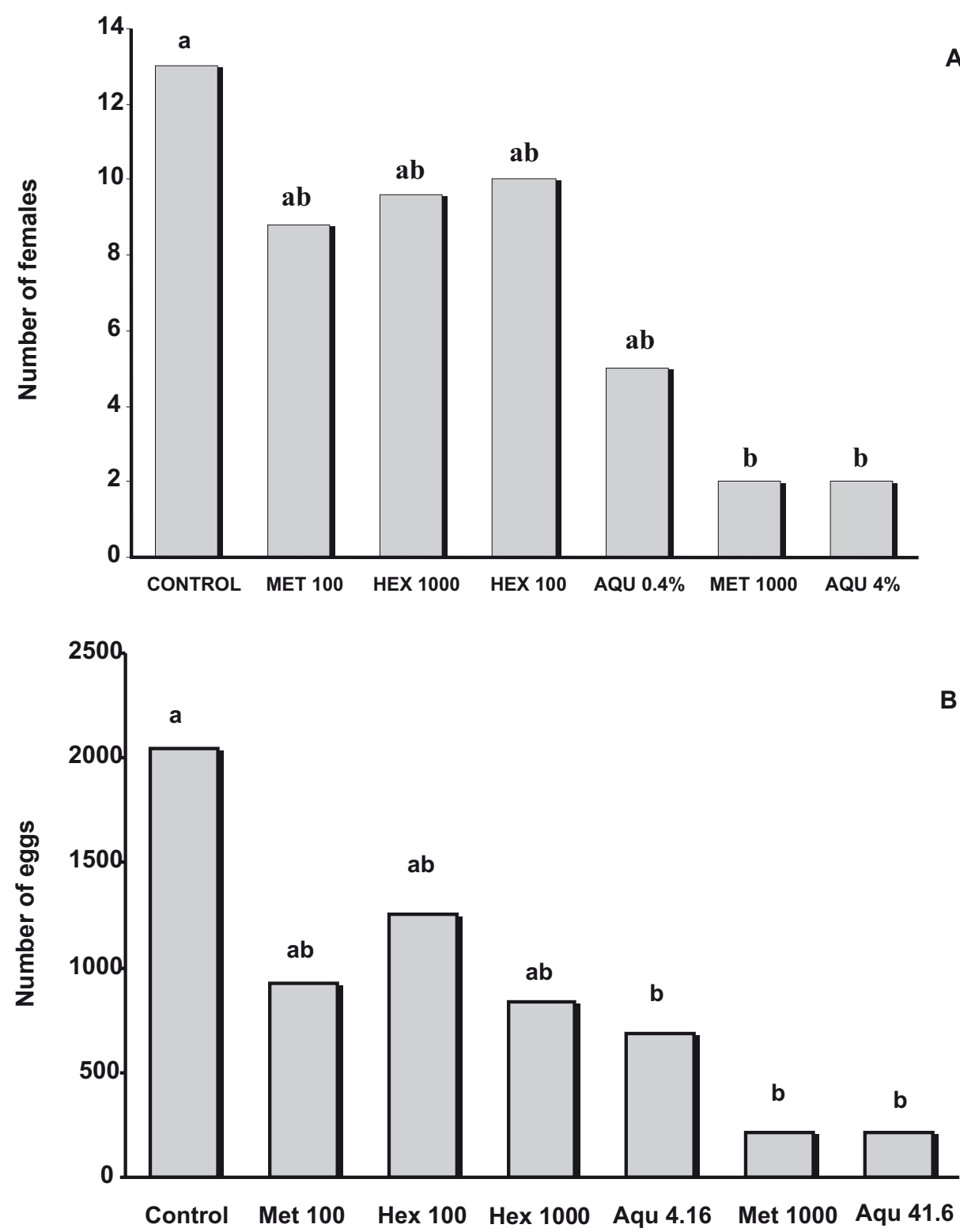

FIG. 3 - Number of Heterodera glycines females (A) and eggs (B) per root system of soybean plants inoculated with treated second-stage juveniles (J2) with neem extracts. ( $\mathrm{n}=5$ replicates). Data regarding number of females transformed in $\sqrt{x+1 / 2}$. Averages followed by the same letter do not differ by the Tukey test $(\mathrm{P}=0.05)$. Control $=$ soybean plants inoculated with non treated $\mathrm{J} 2$. Aqu 4.16 and Aqu 0.416 represent treatments with aqueous extract at a concentration of 41.6 and $4.16 \mathrm{mg} \mathrm{L}^{-1}$; Met 1,000 and Met $100=$ methanolic extract at a concentration of 1000 and $100 \mathrm{mg} \mathrm{L}^{-1}$; Hex 1,000 and Hex $100=$ hexane extract at a concentration of 1000 and $100 \mathrm{mg} \mathrm{L}^{-1}$, respectively.

$\mathrm{mg} \mathrm{L}^{-1}$. Once again the aqueous extracts were more effective than the corresponding methanolic extracts.

\section{Qualitative HPLC analysis}

Seven tetranortriterpenoids, namely azadirachtin $\mathrm{H}$, azadirachtin $\mathrm{A}$, azadirachtin $\mathrm{B}$, desacetylnimbim, desacetylsalannin, nimbin and salannin, were identified in
A

B 

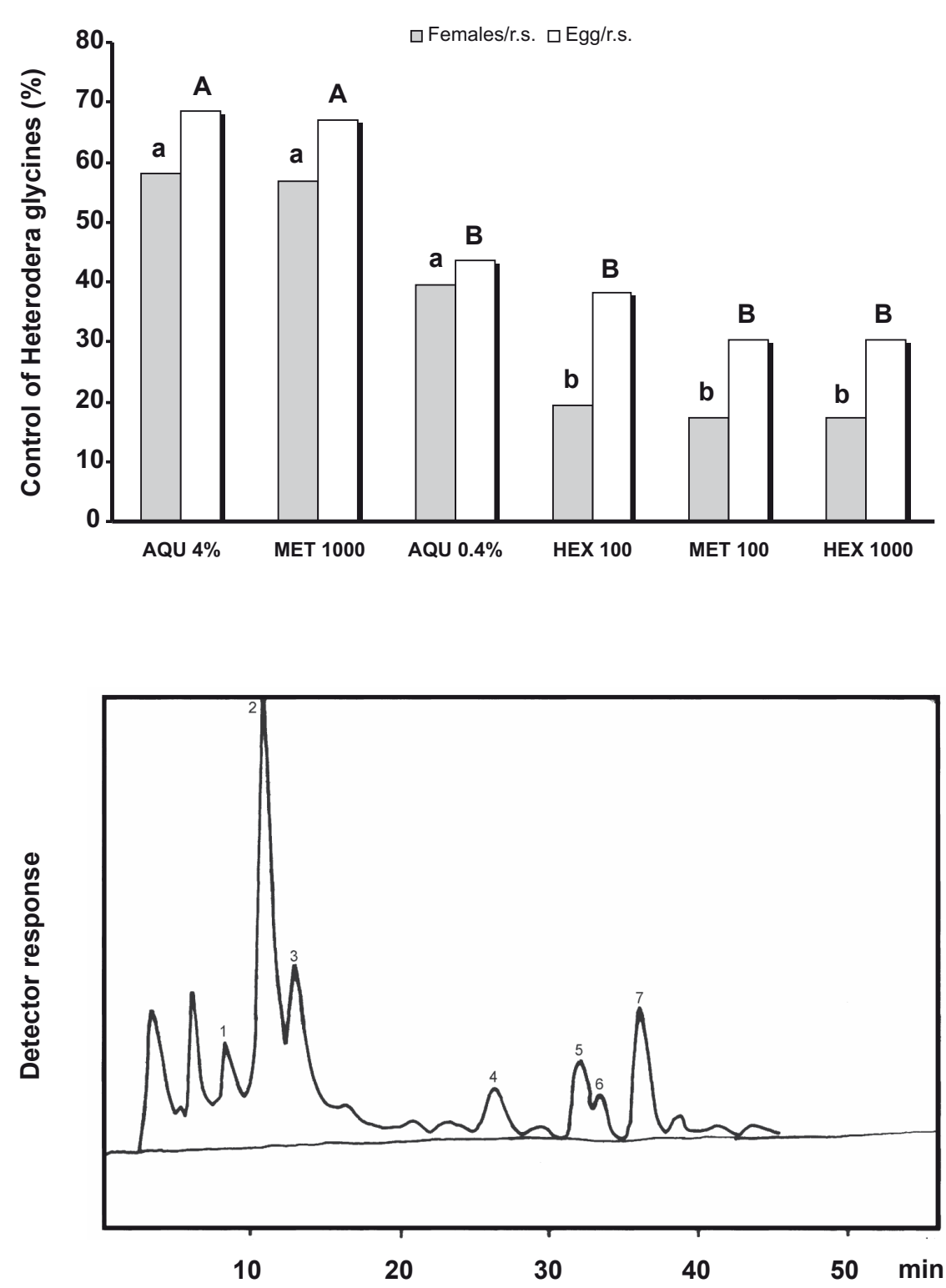

FIG. 4 - Percentage of Heterodera glycines control on soybean plants, based on the reduction of the number of females and eggs, after inoculation with treated second-stage juveniles with neem extracts. $(n=5$ replicates). Data of number of females were transformed by . Averages followed by the same letter do not differ by the Scott-Knott test $(\mathrm{P}=0.05)$. Aqu 4.16 and Aqu 0.416 represent treatments with aqueous extract at a concentration of 41.6 and $4.16 \mathrm{mg} \mathrm{L}-1$; Met 1,000 and Met 100 $=$ methanolic extract at a concentration of 1000 and $100 \mathrm{mg} \mathrm{L}-1$; Hex 1,000 and Hex $100=$ hexane extract at a concentration of 1000 and $100 \mathrm{mg} \mathrm{L}-1$, respectively.
FIG. 5 - HPLC trace obtained by analysis of neem seed methanolic extracts with sequential extraction. Peaks 1 to 7 were identified as azadirachtin $\mathrm{H}$, azadirachtin A, azadirachtin B, desacetylnimbim, desacetylsalannin, nimbin and salannin, respectively. For experimental conditions see experimental section. gradient) were evaluated with a UV-VIS detector. However, no major separation was achieved under these conditions. A reasonable separation and response was obtained on a column, and conditions used to separate carbohydrates with a refractive index detector with water/acetonitrile as the solvent and as it can be observed, about 13 peaks were recorded (Figure 6). The retention times of these peaks did not correspond to the tetranortriterpenoids (azadirachtin A, azadirachtin B, salannin, desacetylsalannin, nimbin, desacetylnimbin) reported in neem.

\section{DISCUSSION}

Activity of the aqueous neem extract against several nematodes was reported (Rao et al., 1997; Khurma \& Singh, 1997; Debanand et al., 2000), including in the previous preliminary studies with $H$. glycines (Rodrigues et al., 2001) as well as with these results (Figure 1). Although the aqueous extract has been studied and its effectiveness has already been confirmed in nematode control, it has not been chemically characterized. It was not unexpected to find the 13 peaks on the aqueous extract, nor to note that their retention times did not correspond to the tetranortriterpenoids reported in neem. Sharma et al. (2003) observed the azadirachtins obtained by the solvent system methanol/water gave only one peak when profiled by HPLC, but other peaks at different retention times were exhibited when azadirachtins $\mathrm{A}, \mathrm{B}$ and $\mathrm{H}$ were isolated by MPLC (medium pressure liquid chromatography). Thus, a higher resolution would be obtained under gradient elution and an appropriate detector, e.g. a light-sensitive or a mass spectrometer. 


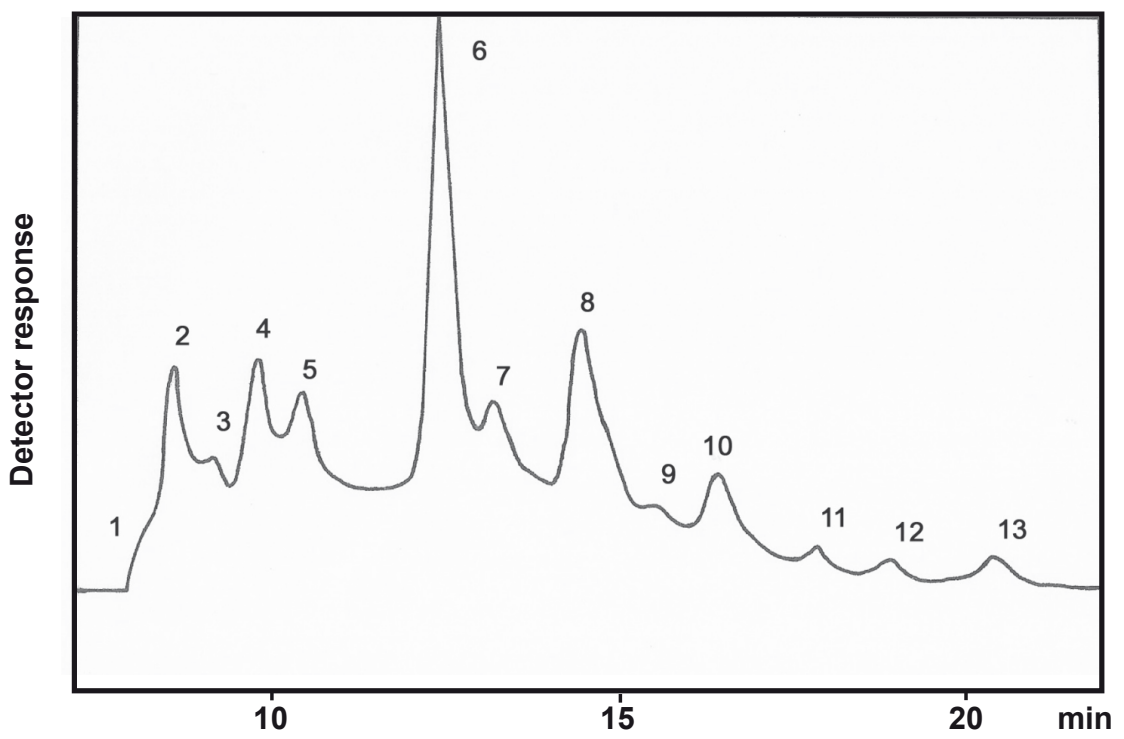

FIG. 6 - HPLC trace obtained by analysis of neem seed crude aqueous extract using a refractive index detector. The mobile phase was acetonitrile/ water $(6: 4, v / v)$ at a flow rate of $0.5 \mathrm{~mL} \mathrm{~min}^{-1}$ with a Techsphere column (NH2, $5 \mu \mathrm{mm}, 250 \mathrm{x}$ $4.6 \mathrm{~mm}$ id).
However, it is possible that the biological effect is associated to those molecules detected in purified extracts, as in NSC. The activity of this extract was related to the presence of seven tetranortriterpenoids such as azadirachtin $\mathrm{H}$, azadirachtin A, azadirachtin B, desacetylnimbim, desacetylsalannin, nimbin salannin. The efficiency of the NSC on Rotylenchulus reniformis was also demonstrated by Sharma et al. (2003). These authors showed a 50\% reduction in $R$. reniformis juveniles (J4) at a dosage of $151 \mathrm{mg} \mathrm{L}^{-1}$ after $72 \mathrm{~h}$ exposure to NSC extract. The activity was attributed mainly to azadirachtin A and, to a lesser extent, to its other isomers. Budh Ram \& Baheti (2003) successfully managed $R$. reniformis on cowpea seeds treated with neem.

The activities of the hexane and methanolic extracts could be explained in terms of their chemical compositions. The hexane extract essentially contains lipids (triacylglycerols) (Johnson \& Morgan, 1997b), which are non-toxic and fit for human consumption (Chinnasamy et al., 1993). Under the present experimental conditions, the hexane extract was also apparently not toxic to J2. The toxicity of the methanolic extracts is in agreement with other literature studies where tetranortriterpenoids were reported in neem seed and activity related to several pathogens (Govindachari et al., 1990, 1998; Jarvis et al., 1999; Johnson \& Morgan, 1997a, b; Martinez, 2002; Sharma et al., 2003; Barrek et al., 2004).

Both aqueous neem extract and methanolic neem extract, at higher concentrations, were effective in reducing the number of $H$. glycines females and eggs on soybean cultivated under greenhouse (almost 90\%) and in vitro $\mathrm{J} 2$ mortality (almost 100\%). The nematicidal activity of neem vegetative parts has been reported not only on soybean cysts nematode but also on several other nematodes. Rossner \& Zebitz (1986), utilizing ground neem seed and leaves (1\%), obtained a significant reduction of Meloidogyne arenaria and
Pratylenchus penetrans in tomato. Vyas (1993) reported a significant reduction in soybean nematodes Helicotylenchus sp., Xiphinema sp. and Aphelenchus sp. at dosages of 2 $\mathrm{g}$ of neem seed per $\mathrm{Kg}$ of soil. Similar studies have been reported for several other nematodes, such as Tylenchulus semipenetrans (Ahmad et al., 2004); Rotylenchulus reniformis (Budh Ram \& Baheti, 2003); Heterodera cajani (Nageswari \& Mishra 2001; 2005; Haseeb \& Shukla, 2004; Mojumder \& Mittal, 2003); M. graminicola (Prasad et al., 2005); M. incognita (Scramim et al., 1987; Shah et al., 2003) and Steinernema feltiae (Krishnaya \& Grewal, 2002).

The higher toxicity of the hexane extracts related to the level of control (greenhouse) as compared to the in vitro assay (J2 mortality) was difficult to explain. Thus, although the hexane extracts did not cause $\mathrm{J} 2$ mortality they apparently interfered with other development stages of the nematode. This is in agreement with well-known effects of conventional nematicides (Spurr Junior, 1985), where a majority of systemic nematicides cause a disorientation of the nematodes in the soil preventing penetration in the plant roots. However, as soon as the active ingredient of the nematicides has stopped working, the nematodes recover their perception system and enter the host plant, where they continue developing.

Towards methanolic and aqueous neem extracts, the results have shown that both were efficient, significantly interfering in the development of $H$. glycines on soybean, and aqueous extract had a higher effect. The methanolic and the aqueous neem extracts were seen to be an alternative for control of $H$. glycines. The water extract seems to be a better alternative since it is easier to prepare and less expensive and maybe not toxic. In areas infested with soybean cyst nematodes, using neem extracts on contaminated small patches can reduce nematode dissemination. Considering that the small patches of infested areas are gradually enlarged 
to encompass significant areas of disease and the spread of these nematodes within fields is usually accelerated by cultural practices of the grower, applying neem extracts on these areas appears to be an effective restraint, which may decrease nematode populations and consequently reduce the dissemination of $H$. glycines.

\section{ACKNOWLEDGEMENTS}

This research was partly supported by Fundação de Amparo à Pesquisa do Estado de Minas Gerais - FAPEMIG. The authors gratefully acknowledge a scholarship given by Conselho Nacional de Desenvolvimento Científico e Tecnológico - CNPq.

\section{REFERENCES}

Ahmad MS, Tariq-Mukhtar, Riaz-Ahmad (2004) Some studies on the control of citrus nematode (Tylenchulus semipenetrans) by leaf extracts of three plants and their effects on plant growth variables. Asian Journal of Plant Sciences 3:544-548.

Akhtar M, Akhtar M (2000) Nematicidal potential of the neem tree (Azadirachta indica A. Juss). Integrated Pest Management Reviews 5:57-66.

Barrek S, Paisse O, Grenier-Loustalot MF (2004) Analysis of neem oils by LC-MS and degradation kinetics of azadirachtin-A in a controlled environment - Characterization of degradation products by HPLC-MS-MS. Analytical and Bioanalytical Chemistry 378:753-763.

Budh Ram, Baheti BL (2003) Management of reniform nematode, Rotylenchulus reniformis on cowpea through seed treatment with botanicals. Current Nematology 14:27-30.

Chen SY, Dickson DW (2000) A technique for determining live second-stage juveniles of Heterodera glycines. Journal of Nematology 32:117-121.

Chinnasamy N, Harishankar N, Uday Kumar P, Rukmini C (1993) Toxicological studies on debitterized neem oil (Azadirachta indica). Food and Chemical Toxicology 31:297-301.

Debanand DAS, Prabal Saikia L, Saikia P (2000) Effect of certain plant extracts on rice root-knot nematode, Meloidogyne graminicola. Journal of the Agricultural Science Society of NorthEast India 13:85-87.

Dias WP, Silva JFV, Garcia AP, Carneiro GES (2007) Nematóides de importância para a cultura da soja no Brasil. In: Boletim de Pesquisa da Soja 2007. Rondonópolis MT, Fundação MT (Org.) pp. 173-183.

Euclydes RF (1983) Manual de utilização do programa SAEG (Sistema para Análises Estatísticas e Genéticas). Viçosa MG. Editora Universidade Federal de Viçosa.

Govindachari TR, Sandhya G, Ganesh-Raj SP (1990) Simple method for the isolation of azadirachtin by preparative high performance liquid chromatography. Journal of Chromatography 513:389-391.

Gupta P, Sebastian S, Sobita LR, Mishra SM (1993) Use of neem cake in control of lesion nematode, cyst nematode and root knot nematode. World Neem Conference, India, 65:621-625.

Haseeb A, Shukla PK (2004) Management of Heterodera cajani, Meloidogyne incognita and Fusarium wilt on pigeon-pea with some chemicals, bio-pesticides and bio-agents. Nematologia Mediterranea 32:217-222.

Jarvis AP, Morgan ED, Edwards C (1999) Rapid separation of triterpenoids from neem seed extracts. Phytochemical Analysis 10:39-43.

Johnson S, Morgan ED (1997a) Comparison of chromatographic systems for triterpenoids from neem (Azadirachta indica) seeds. Journal of Chromatography A 761:53-63.

Johnson S, Morgan ED (1997b) Supercritical fluid extraction of oil and triterpenoids from neem seeds. Phytochemical Analysis 8:228232.

Khurma UR, Singh A (1997) Nematicidal potential of seed extracts: in vitro effects on juvenile mortality and egg hatch of Meloidogne incognita and M. javanica. Nematologia Mediterranea 25:49-54.

Kimura Y, Mori MS, Suzuki A, Mitsui Y (1981) A rapid and simple method for assay of nematicidal activity and its application to measuring the activities of dicarboxylic esters. Agriculture and Biological Chemistry 45:249-251.

Krishnaya PV, Grewal PS (2002) Effect of neem and selected fungicides on viability and virulence of the entomopathogenic nematode Steinernema feltiae. Biocontrol Science and Technology 12:259-266.

Kumar CS, Srinivas M, Yakkundi S (1996) Limonoids from the seeds Azadirachta indica. Phytochemistry 43:451-455.

Lima RD, Ferraz S (1985) Biologia de Meloidogyne exigua. II. Desenvolvimento pós-embriogênico em cafeeiro 'Mundo Novo'. Revista Ceres 32:349-361.

Martinez SS (2002) O Nim - Azadirachta indica: Natureza, Usos Múltiplos, Produção. Londrina, Brazil: IAPAR.

Mendes ML (1993) O nematóide do cisto da soja (Heterodera glycines Ichinohe 1952). In: Arantes NE, Souza PIM (Eds.) Cultura da soja nos cerrados. Piracicaba SP. Potafós. pp. 399-413.

Mojumder V, Mittal A (2003) Effect of neem products as seed coating against Heterodera cajani in cowpea. Legume Research 26:231-232.

Mourão AS, Zanuncio JC, Silva JCT, Jham GN (2004) Nim Indiano (Azadirachta indica) - Mil utilidades. Viçosa MG. Universidade Federal de Viçosa.

Nageswari S, Mishra SD (2001) Effect of different neem formulations as soil application at different doses against Heterodera cajani infecting pigeonpea. Current Nematology 12:21-23.

Nageswari S, Mishra SD (2005) Integrated nematode management schedule incorporating neem products, VAM and soil solarization against Heterodera cajani infecting pigeon pea. Indian Journal of Nematology 35:68-71.

National Research Council (1992) Neem: A tree for solving global problems. Washington D.C. National Academy Press. pp. 31-38.

Prasad JS, Varaprasad KS, Rao YR, Rao ES, Sankar M (2005) Comparative efficacy of some oil seed cakes and extracts against root-knot nematode (Meloidogyne graminicola) infection in rice. Nematologia Mediterranea 33:191-194.

Rao MS, Reddy PP, Nagesh M (1997) Effective use of neem cake 
extract for the management of root-knot nematodes infecting okra (Abelmoschus esculentus). Pest Management in Horticultural Ecosystems 3:95-99.

Rodrigues AC, Jham GN, Oliveira RD (2001) Mortality of the soybean cyst nematode in aqueous extracts of neem plant. Nematologia Mediterranea 29:173-175.

Rossner J, Zebitz CPW (1986) Effect of neem products on nematodes on tomato (Lycopersicon esculentum) plants. In: Proceedings of the $3^{\text {rd }}$ International Neem Conference, Nairobi, Kenya. pp. 10-15.

Scramim S, Fernandes LMS, Silva HP, Yahn CA (1987) Avaliação biológica de extratos de 14 espécies vegetais sobre Meloidogyne incognita raça 1. Nematologia Brasileira 11:89-102.

Sharma V, Walia S, Kumar J, Nair MG, Parmar BS (2003) An efficient method for the purification and characterization of nematicidal Azadirachtins A, B, and H, using HPLC and ESIMS. Journal of Agricultural and Food Chemistry 51:3966-3972.

Siddiqui MA, Alam MM (1993) Evaluation of nematicidal potential in neem allelochemicals.In: Singh RP, Chari MS, Raheja AK, Kraus
W (Eds.) Neem and Environment. World Neem Conference. New Delhi, India. Oxford and IBH Publishing Co.

Silva JFV, Garcia A (2004) Nematóide de cisto da soja: Situação atual e perspectivas. In: I Encontro Regional sobre nematóide de Cisto da Soja -1996. Dourados MS. EMBRAPA-CPAO/SEIVA, pp. 13-18.

Silva JCT, Jham GN, Oliveira RDL, Brown L (2007) Purification of the seven tetranortriterpenoids in neem (Azadirachta indica) seed by counter-current chromatography sequentially followed by isocratic preparative reversed-phase high-performance liquid chromatography. Journal of Chromatography A 1065:203-210.

Spurr Junior HW (1985) Mode of action of nematicides. In: Sasser JN, Carter CC (Eds.) An Advanced Treatise on Meloidogyne. North Carolina. North Carolina State University Graphics. pp. 269-276.

Vyas SC (1993) Effect of neem cake, neem oil, repelin and carbofuran on control of soybean nematodes. In: Singh RP, Chari MS, Raheja AK, Kraus W (Eds.) Neem and Environment. World Neem Conference, New Delhi, India. Oxford and IBH Publishing Co. pp. 663-667.

Received 2 July 2007 - Accepted 28 April 2008 - TPP 7081 Associate Editor: Regina Maria D.G. Carneiro 